\title{
HUBUNGAN KPD, JANIN BESAR DAN INERSIA UTERI DENGAN KEJADIAN KALA II
}

\author{
Dewi Novitasari ${ }^{1}$ Herawati $^{2}$, Rizki Amalia ${ }^{3}$ \\ Program Studi Di ploma IV Kebidanan Universitas Kader Bangsa Palembang \\ J1. Mayjend. H.M Ryacudu No.88 Palembang Telp (0711)517744-510173 \\ Email : dewidenosas231195@gmail.com
}

\begin{abstract}
Abstrak
Kala 2 lama terjadi ketika serviks mencapai dilatasi penuh, jangka waktu sampai terjadinya kelahiran tidak boleh melampaui 2 jam pada primigravida dan 1 jam pada multipara. Tujuan Penelitian Ini Untuk Mengetahui Hubungan KPD, Janin Besar Dan Inersia Uteri DenganKejadian Kala II Lama Di Rumah Sakit Islam Siti Khadijah Kota Palembang Tahun 2018. Metode Yang Digunakan Dalam Penelitian Ini Adalah Survey Analitik Dengan Pendekatan Cross Sectional. Uji Statistik Yang Digunakan Adalah Uji Chi-Square. Populasi Dalam Penelitian Ini Adalah Semua Ibu Bersalin Di Rumah Sakit Islam Siti Khadijah Kota Palembang Tahun 2018 Dengan Total Populasi 659 Ibu Bersalin Dan Total Sampel Berjumlah 87 Responden. Analisis Yang Digunakan Adalah Analisis Univariat Dan Analisis Bivariat. Analisis Univariat Didapatkan Dari 87 responden, proporsi ibu yang mengalami kala II lama sebanyak 28 responden $(32,2 \%)$ lebih kecil dibandingkan dengan ibu yang tidak mengalami Kala II lama sebanyak 59 responden $(67,8 \%)$.dari hasil uji statistik menggunakan Uji Chi-Square didapatkan hasil bahwa ada hubungan yang bermakna antara KPD dengan kejadian kala II Lama $p$ Value $=0,005 \leq 0,05$, untuk Janin besar dengan kejadian Kala II lama $p$ Value =0,016 $\leq 0,05$ dan ada hubungan yang bermakna antara inersia uteri dengan kejadian kala II Lama $p$ Value =0,012 $\leq 0,05$.Hasil penelitian ini diharapkan untuk dapat memberikan asuhan kebidanan yang baik dan benar kepada ibu bersalin agar tidak terjadi kala II lama.
\end{abstract}

Kata kunci $\quad$ : KPD, Janin Besar, Inersia Uteri dan Kala II Lama

\begin{abstract}
The second stage occurs when the cervix reaches full dilatation, the time until birth can not exceed 2 hours in primigravida and 1 hour in multiparas. The Purpose of this research is to find out the relationship between the KPD, the large fetus and the uterine inertia with the old second event at the Siti Khadijah Islamic Hospital in Palembang in 2018. The method used in this study is an analytical survey with a cross sectional approach. The Statistical Test Used is the Chi-Square Test. The population in this study were all mothers giving birth at the Siti Khadijah Islamic Hospital in Palembang City in 2018 with a total population of 659 maternity and a total sample of 87 respondents. The Analysis Used Is Univariate Analysis and Bivariate Analysis. Univariate Analysis Obtained From 87 respondents, the proportion of mothers who experienced the old stage II were 28 respondents (32.2\%) smaller than the mothers who did not experience the old stage II as many as 59 respondents (67.8\%). Chi-Square showed that there was a significant relationship between the KPD and the occurrence of the second stage of the Old $p$ Value $=0.0055$ 0.05, for the large fetus with the incidence of the old stage II Value $=0.01650 .05$ and there was a significant relationship between uterine inertia with the occurrence of second time duration $p$ Value $=0.012 \leq 0.05$. The results of this study are expected to be able to provide good and correct midwifery care to maternity so as not to occur in the second time.
\end{abstract}

Keywords $\quad: K P D$, Large Fetus, Uteri Inertia and Old Kala II 


\section{PENDAHULUAN}

Data World Heald Organization (WHO) pada tahun 2015, menegaskan setiap tahun diseluruh dunia 358.000 ibu meninggal saat hamil atau bersalin dimana 355.000 ibu (99\%) berasal dari negara berkembang termasuk Indonesia. Rasio kematian ibu di negara - negara berkembang merupakan grade tertinggi dengan 290 kematian ibu di negara maju, yaitu 14 kematian ibu per 100.000 kelahiran hidup salah satu penyebabnya yaitu kala II lama 25(8.62\%) dari 290 $/ 100.000$ kelahiran hidup. Sedangkan setiap tahunnya 120 juta bayi lahir didunia, secara global 4 juta (33 per 1000) bayi lahir mati dan 4 juta (33 per 1000) lainnya meninggal dalam usia 30 hari (neonatal lanjut). Kira-kira 3,6 juta (3\%) dari 120 juta bayi mengalami asfiksia neonatorum, hampir 1 juta $(27,78 \%)$ bayi ini meninggal (WHO, 2017).

Data survey Demografi Kesehatan Indonesia (SDKI) 2016, angka kematian ibu (AKI) tercatat mencapai 359/100.000 kelahiran hidup. rata-rata kematian ini jauh melonjak dibandingkan hasil SDKI 2010 yang mencapai 228/100.000 kelahiran hidup. Penyebab langsung yaitu pendarahan $(42 \%)$, eklamsia atau preeklamsia (30\%), abortus (11\%), infeksi (10\%), persalinan lama $33(9 \%)$ dan penyebab lain (15\%) sedangkan jumlah angka kematian Bayi (AKB) pada tahun 2014 sebesar 34/1000 kelahiran hidup, tahun 2015 sebesar 34/1000 kelahiran hidup. Tahun 2016 ,32/1000 kelahiran hidup, Penyebab kematian Bayi Baru Lahir (BBL) diantaranya adalah asfiksia (27\%) yang merupakan penyebab ke 2 setelah Bayi Berat Lahir Rendah (BBLR) dan penyebab tersebut diakibatkan salah satunya karena persalinan kala II lama (SDKI, 2018).

Angka kematian ibu di Sumatra Selatan pada tahun 2015, sebesar 148 per 100.000 kelahiran hidup, sedangkan pada tahun 2016 AKI di Sumatera Selatan sebesar 131 per 100.000 kelahiran hidup sedangkan Jumlah Angka kelahiran pada tahun 2015 yaitu 156.348 orang dengan Angka kematian bayi (AKB) yaitu 537 kematian bayi $(3,4 \%)$, sedangkan pada tahun 2016 jumlah kelahiran 102.205 dengan Angka kematian bayi (AKB) yaitu 79 kematian bayi $(0,8 \%)$. Persentase kematian tertinggi terjadi di Kabupaten Ogan Komering Ilir (OKI) $(1,31 \%)$ dan Lahat $(0,82 \%)$, persentase terendah di Kabupaten Muara Enim (0,14\%) dan Empat Lawang (0,13\%) (Dinkes Provinsi Sumsel, 2017).

Data Dinkes Kota Palembang tahun 2016 jumlah kematian ibu masih dibawah angka Nasional untuk RPJMN (Rencana Pembangunan Jangka Menengah Nasional) tahun 2015 (118 per 100.000 kelahiran hidup), tahun 2016 Ada 13 kasus kematian ibu dari 29.911 kelahiran hidup, penyebab kematian terbanyak adalah pre eklampsia berat $(31 \%)$, diikuti oleh hipertensi dalam kehamilan (23\%) perdarahan (15\%), syok hipovolemik $(8 \%)$, persalinan lama $(8 \%)$ dan lain-lain (15\%). Sedangkan Angka Kematian Bayi (AKB) pada tahun 2015 sebanyak $1,5 \%$ per 1.000 kelahiran hidup, meningkat pada tahun 2016 sebesar 1,6\% per 1.000 kelahiran hidup, meningkat kembali pada tahun 2017 sebanyak 1,8\% per 1.000 kelahiran hidup dan semua itu disebabkan berbagai masalah mulai dari pernapasan (asfiksia) yang disebabkan karena persalinan kala II lama (Profil Dinkes Kota Palembang, 2017).

Data survei pendahuluan dari Medical Record di Rumah Sakit Islam Siti Khadijah Palembang didapatkan pada tahun 2016 tercatat $35(15,76 \%)$ ibu yang mengalami persalinan kala II lama dari 222 jumlah ibu bersalin, Pada tahun 2017 tercatat $55(16,71 \%)$ ibu yang mengalami persalinan kala II lama dari 329 jumlah ibu bersalin, Sedangkan, pada tahun 2018 tercatat $110 \quad(16,69 \%)$ ibu yang mengalami persalinan kala II lama dari 659 jumlah ibu bersalin (RSI Siti Khadijah Palembang, 2019). 


\section{METODE PENELITIAN}

Jenis penelitian ini bersifat kuantitatif dengan menggunakan Survey Analitik dengan pendekatan cross sectional, dimana variabel independen (KPD, janin besar dan inersia uteri) dan variabel dependen (kejadian kala II lama) diambil atau dikumpulkan dalam waktu bersamaan (Notoatmodjo, 2012).

\section{Jenis Penelitian}

Jenis penelitian ini bersifat kuantitatif dengan menggunakan Survey Analitik dengan pendekatan cross sectional.

\section{Waktu dan Tempat Penelitian}

Penelitian ini Telah dilaksanakan pada bulan Mei-Juni 2019 dan Penelitian ini Telah dilaksanakan di Rumah Sakit Islam Siti Khadijah Palembang.

\section{Target/Subjek Penelitian}

Populasi adalah keseluruhan dari objek yang akan kita teliti (Notoatmodjo, 2012). Populasi dalam penelitian ini adalah semua ibu bersalin di Rumah Sakit Islam Siti Khadijah Palembang pada bulan Januari-Desember tahun 2018 yang berjumlah 659orang.

Sampel pada penelitian ini adalah sebagian ibu bersalin di Rumah Sakit Islam Siti Khadijah Palembang yang berjumlah 87 orang. Dan Teknik pengambilan sampel pada penelitian ini dilakukan secara sistematis random sampling.

\section{Data, Intrumen, dan Teknik Pengumpulan Data}

Data sekunder, yaitu data atau sumber informasi yang bukan dari tangan pertama dan yang bukan mempunyai wewenang dan tanggung jawab terhadap informasi atau data tersebut. (Notoatmodjo, 2012).

Pada penelitian ini peneliti menggunakan data sekunder yang didapatkan dari catatan rekam medik
Rumah Sakit Islam Siti Khadijah Palembang.

\section{Teknik Analisa Data}

Analisa Univariat adalah analisa data yang dilakukan untuk mengetahui distribusi frekuensi dari tiap-tiap variabel, dari variabel independen (KPD, janin besar dan inersia uteri) dan variabel dependen (kejadian kala II lama).

Analisa Bivariat adalah analisa ini bertujuan untuk melihat hubungan antara dua variabel yaitu: variabel dependen yaitu kejadian kala II lama dan variabel independen KPD, janin besar dan inersia uteri dengan menggunakan uji statistic Chi-Square dengan batas kemaknaan $\alpha=$ 0,05 . Keputusan hasil statistic diperoleh dengan cara membanding $P$ value dengan $\alpha$ keputusannya hasil uji statistik, yaitu :

1. Apabila $P$ value $\leq \alpha=0,05$ berarti ada hubungan yang signifikan antara variabel independen dengan variabel dependen.

2. Apabila $P$ value $>\alpha=0,05$ berarti tidak ada hubungan yang signifikan antara variabel independen dengan variabel dependen (Notoatmodjo, 2012).

HASIL PENELITIAN

Tabel 1: SDM RSI Siti Khadijah Palembang

\begin{tabular}{llc}
\hline No & \multicolumn{1}{c}{ Jenis Ketenagaan } & Jumlah \\
\hline 1 & Dokter Umum & 15 Orang \\
\hline 2 & Dokter Spesialis & 74 Orang \\
\hline 3 & Dokter Gigi & 2 Orang \\
\hline 4 & Paramedic keperawatan & 237 Orang \\
\hline 5 & Paramedic dan keperawatan & 55 Orang \\
\hline 6 & Non medis & 228 Orang \\
\hline 7 & Dokter Konsultan & 61 Orang \\
\hline 8 & Dokter Umum Partime & 7 Orang \\
\hline & JUMLAH & 679 Orang
\end{tabular}

Tabel 2 : Distribusi Frekuensi Dan Persentase Berdasarkan Kejadian Kala II Lama Pada Ibu Bersalin di RSI Khadijah Palembang tahun 2018 


\begin{tabular}{cccc}
\hline No & $\begin{array}{c}\text { Kala II } \\
\text { Lama }\end{array}$ & $\begin{array}{c}\text { Frekuensi } \\
(\mathrm{N})\end{array}$ & Persentase \% \\
\hline 1 & Ya & 28 & $32,2 \%$ \\
\hline 2 & Tidak & 59 & $67,8 \%$ \\
\hline Jumlah & 87 & $100 \%$ \\
\hline
\end{tabular}

Dari tabel 2 diatas, dapat dilihatdari 87 responden, proporsi ibu yang mengalami kala II lama adalah sebanyak 28 responden (32,2\%) lebih kecil dibandingkan dengan ibu yang tidak mengalami Kala II lama yaitu sebanyak 59 responden $(67,8 \%)$.

Tabel 3 : Distribusi Frekuensi Dan Persentase Berdasarkan KPDPada Ibu Bersalin Di RSI Siti Khadijah Palembang Tahun 2018

\begin{tabular}{cccc}
\hline No & KPD & $\begin{array}{c}\text { Frekuensi } \\
(\mathrm{N})\end{array}$ & $\begin{array}{c}\text { Persentase } \\
\%\end{array}$ \\
\hline 1 & Ya & 20 & $23,0 \%$ \\
\hline 2 & Tidak & 67 & $77,0 \%$ \\
\hline Jumlah & 87 & $100 \%$ \\
\hline
\end{tabular}

Dari tabel 3 diatas, dapat dilihat bahwa dari 87 responden, proporsi ibu bersalin yang mengalami KPD adalah sebanyak 20 responden $(23,0 \%)$, lebih kecil dibandingkan dengan ibu bersalin yang tidak mengalami KPD yaitu sebanyak 67 responden $(77,0 \%)$

Tabel 4 : Distribusi Frekuensi Dan Persentase Berdasarkan Janin BesarPada Ibu Bersalin di RSI Siti Khadijah Palembang tahun 2018

\begin{tabular}{cccc}
\hline No & $\begin{array}{c}\text { Janin } \\
\text { Besar }\end{array}$ & $\begin{array}{c}\text { Frekuensi } \\
(\mathrm{N})\end{array}$ & $\begin{array}{c}\text { Persentase } \\
\%\end{array}$ \\
\hline 1 & Ya & 15 & $17,2 \%$ \\
\hline 2 & Tidak & 72 & $82,8 \%$ \\
\hline & Jumlah & 87 & $100 \%$ \\
\hline
\end{tabular}

Dari tabel 4 diatas, dapat dilihat dari 87 responden, proporsi ibu yang mengalami Janin besar adalah sebanyak 15 responden (17,2\%), lebih kecil dibandingkan dengan ibu yang tidak mengalami Janin Besar yaitu sebanyak 72 responden $(82,8 \%)$

Tabel 5 : Distribusi Frekuensi Dan Persentase Berdasarkan Inersia Uteri Pada Ibu Bersalin di RSI Siti Khadijah Palembang tahun 2018

\begin{tabular}{cccc}
\hline No & $\begin{array}{c}\text { Inersia } \\
\text { Uteri }\end{array}$ & $\begin{array}{c}\text { Frekuensi } \\
(\mathrm{N})\end{array}$ & $\begin{array}{c}\text { Persentase } \\
\%\end{array}$ \\
\hline 1 & Ya & 6 & $6,9 \%$ \\
\hline 2 & Tidak & 81 & $93,1 \%$ \\
\hline \multicolumn{2}{c}{ Jumlah } & 87 & $100 \%$ \\
\hline
\end{tabular}

Berdasarkan tabel 5 diatas dapat dilihat bahwa dari 87 responden yang diteliti, proporsi ibu yang mengalami inersia uteri adalah sebanyak 6 responden $(6,9 \%)$, lebih kecil dibandingkan dengan ibu yang tidak mengalami inersia uteri yaitu sebanyak 81 responden $(93,1 \%)$.

Tabel 6 : Distribusi Responden Berdasarkan KPD dengan Kejadian Kala II Lama Pada Ibu Bersalin di RSI Siti khadijah Palembang Tahun 2018

\begin{tabular}{|c|c|c|c|c|c|c|c|c|c|}
\hline \multirow{3}{*}{$\begin{array}{l}\mathrm{N} \\
\mathrm{o}\end{array}$} & \multirow{3}{*}{ KPD } & \multicolumn{4}{|c|}{ Kala II Lama } & \multirow{2}{*}{\multicolumn{2}{|c|}{ Jumlah }} & \multirow{3}{*}{ p_value } & \multirow{3}{*}{ OR } \\
\hline & & \multicolumn{2}{|c|}{$\mathrm{Ya}$} & \multicolumn{2}{|c|}{ Tidak } & & & & \\
\hline & & $\mathrm{n}$ & $\%$ & $\mathrm{n}$ & $\%$ & $\mathrm{~N}$ & $\%$ & & \\
\hline 1 & Ya & 12 & $\begin{array}{c}60 \\
0\end{array}$ & 8 & $\begin{array}{c}40 \\
0\end{array}$ & 20 & $\begin{array}{c}10 \\
0\end{array}$ & \multirow{3}{*}{$\begin{array}{c}0,005 \\
\text { Bermak } \\
\text { na }\end{array}$} & \multirow{3}{*}{$\begin{array}{c}4.781 \\
(1,663 \\
- \\
13,74 \\
9)\end{array}$} \\
\hline 2 & Tidak & 16 & $\begin{array}{r}23 \\
, 9 \\
\end{array}$ & 51 & $\begin{array}{l}76 \\
11 \\
\end{array}$ & 67 & $\begin{array}{c}10 \\
0\end{array}$ & & \\
\hline \multicolumn{2}{|c|}{ Jumlah } & 28 & $\begin{array}{l}32 \\
2 \\
\end{array}$ & 59 & $\begin{array}{l}67 \\
8\end{array}$ & 87 & $\begin{array}{c}10 \\
0\end{array}$ & & \\
\hline
\end{tabular}

Berdasarkan tabel 6 diatas, diketahui bahwa dari 20 responden denganKPD, yang mengalami kala II lama sebanyak12 responden $(60,0 \%)$ lebih besar dibandingkan dengan yang tidak mengalami kala II lama sebanyak8 responden (40,0\%). Sedangkan dari 67 responden yang tidak dengan KPD yang mengalami kala II lama sebanyak 16 responden $(23,9 \%)$ lebih kecil dibandingkan dengan yang tidak mengalami kala II lama sebanyak 51 responden $(76,1 \%)$. 
Dari hasil uji chi-square diperoleh P_value $(0,005)<\alpha(0,05)$, yang artinya ada hubungan yang bermakna antara Ketuban Pecah Dini (KPD) dengan kejadian Kala II Lama Pada ibu bersalin. Dengan demikian hipotesis yang menyatakan bahwa ada hubungan antara Ketuban Pecah Dini (KPD) dengan kejadian Kala II Lama Pada ibu bersalin terbukti secara statistik.

Dari hasil analisis diperoleh nilai Odds Ratio $(\mathrm{OR})=4.781$ artinya ibu bersalinyang mengalami KPD mempunyai peluang terjadi Kala II Lama sebanyak 5 kali, dibandingkan ibu bersalinyang tidak mengalami KPD.

Tabel 7 : Distribusi Responden Berdasarkan Janin Besar dengan Kejadian Kala II Lama Pada Ibu Bersalin di RSI Siti khadijah Palembang Tahun 2018.

\begin{tabular}{|c|c|c|c|c|c|c|c|c|c|}
\hline \multirow{3}{*}{$\begin{array}{l}\mathrm{N} \\
\mathrm{o}\end{array}$} & \multirow{3}{*}{$\begin{array}{l}\text { Janin } \\
\text { Besar }\end{array}$} & \multicolumn{4}{|c|}{ Kala II Lama } & \multirow{2}{*}{\multicolumn{2}{|c|}{ Jumlah }} & \multirow{3}{*}{$\begin{array}{l}\mathrm{p}_{-} \\
\text {val } \\
\text { ue }\end{array}$} & \multirow{3}{*}{ OR } \\
\hline & & \multicolumn{2}{|c|}{$\mathrm{Ya}$} & \multicolumn{2}{|c|}{ Tidak } & & & & \\
\hline & & $\mathrm{N}$ & $\%$ & $\mathrm{n}$ & $\%$ & $\mathrm{~N}$ & $\%$ & & \\
\hline \multirow{3}{*}{1} & & & 6 & & 4 & & 1 & \multirow{7}{*}{$\begin{array}{l}0,0 \\
16 \\
\text { Ber } \\
\text { ma } \\
\text { kna }\end{array}$} & 4.1 \\
\hline & $\mathrm{Ya}$ & 9 & 0 & 6 & 0 , & $\begin{array}{l}1 \\
5\end{array}$ & 0 & & 84 \\
\hline & & & 0 & & 0 & & 0 & & ( \\
\hline & & 1 & 2 & 5 & 7 & 7 & 1 & & 1,3 \\
\hline 2 & Tidak & 9 & $\begin{array}{l}6, \\
4\end{array}$ & 3 & $\begin{array}{l}3, \\
6\end{array}$ & 2 & $\begin{array}{l}0 \\
0\end{array}$ & & 14 \\
\hline \multirow{2}{*}{\multicolumn{2}{|c|}{ Jumlah }} & 2 & & 5 & & 8 & 1 & & $\begin{array}{l}13, \\
32\end{array}$ \\
\hline & & 8 & & 9 & & 7 & $\begin{array}{l}0 \\
0\end{array}$ & & 5) \\
\hline
\end{tabular}

Berdasarkan tabel 7 diatas, diketahui bahwa dari 15 responden dengan Janin Besar, yang mengalami kala II lama sebanyak 9 responden $(60,0 \%)$ lebih besar dibandingkan dengan yang tidak mengalami kala II lama sebanyak 6 responden $(40,0 \%)$. Sedangkan dari 72 responden tidak dengan Janin Besar yang mengalami kala II lama sebanyak 19 responden (26,4\%) lebih kecil dibandingkan dengan yang tidak mengalami kala II lama sebanyak 53 responden $(73,6 \%)$.

Dari hasil uji chi-square diperoleh $P \_$value $(0,016)<\alpha(0,05)$, yang artinya ada hubungan yang bermakna antara Janin Besar dengan kejadian Kala II Lama Pada ibu bersalin. Dengan demikian hipotesis yang menyatakan bahwa ada hubungan antara Janin Besar dengan kejadian Kala II Lama Pada ibu bersalin terbukti secara statistik.

Dari hasil analisis diperoleh nilai Odds Ratio $(\mathrm{OR})=4.184$ artinya ibu bersalin yang mengalami Janin Besar mempunyai peluang terjadi Kala II Lama sebanyak 4 kali, dibandingkan ibu bersalin yang tidak mengalami Janin Besar.

Tabel 8 : Distribusi Responden Berdasarkan Inersia Uteri dengan Kejadian Kala II Lama Pada Ibu Bersalin di RSI Siti khadijah Palembang Tahun 2018

\begin{tabular}{|c|c|c|c|c|c|c|c|c|c|}
\hline \multirow{3}{*}{$\begin{array}{l}\mathrm{N} \\
\mathrm{O}\end{array}$} & \multirow{3}{*}{$\begin{array}{c}\text { Inersia } \\
\text { Uteri }\end{array}$} & \multicolumn{4}{|c|}{ Kala II Lama } & \multirow{2}{*}{\multicolumn{2}{|c|}{ Jumlah }} & \multirow{3}{*}{$\begin{array}{c}\text { p_va } \\
\text { lue }\end{array}$} & \multirow{3}{*}{ OR } \\
\hline & & \multicolumn{2}{|c|}{$\mathrm{Ya}$} & \multicolumn{2}{|c|}{ Tidak } & & & & \\
\hline & & $\mathrm{n}$ & $\%$ & $\mathrm{n}$ & $\%$ & $\mathrm{~N}$ & $\%$ & & \\
\hline 1 & Ya & 5 & $\begin{array}{r}83 \\
, 3 \\
\end{array}$ & 1 & $\begin{array}{l}16 \\
, 7 \\
\end{array}$ & 6 & $\begin{array}{c}10 \\
0 \\
\end{array}$ & 0,01 & $\begin{array}{c}12,60 \\
9\end{array}$ \\
\hline 2 & Tidak & 23 & $\begin{array}{r}28 \\
, 4\end{array}$ & 58 & $\begin{array}{l}71 \\
, 6\end{array}$ & 81 & $\begin{array}{c}10 \\
0\end{array}$ & Ber & $\begin{array}{c}(1,396 \\
-\end{array}$ \\
\hline & mlah & 28 & & 59 & & 87 & $\begin{array}{c}10 \\
0\end{array}$ & $\begin{array}{c}\text { mak } \\
\text { na }\end{array}$ & $\begin{array}{c}113,8 \\
71)\end{array}$ \\
\hline
\end{tabular}

Berdasarkan tabel 8 diatas, diketahui bahwa dari 6 responden dengan Inersia Uteri, yang mengalami kala II lama sebanyak 5 responden $(83,3 \%)$ lebih besar dibandingkan dengan yang tidak mengalami kala II lama sebanyak 1 responden $(16,7 \%)$. Sedangkan dari 81 responden yang tidak dengan Inersia Uteri yang mengalami kala II lama sebanyak 23 responden $(28,4 \%)$ lebih kecil dibandingkan dengan yang tidak mengalami kala II lama sebanyak 58 responden $(71,6 \%)$.

Dari hasil uji chi-square diperoleh $P_{\text {_value }}(0,012)<\alpha(0,05)$, yang artinya ada hubungan yang bermakna antara Inersia Uteri dengan kejadian Kala II Lama Pada ibu bersalin. Dengan demikian hipotesis yang menyatakan bahwa ada hubungan antara Inersia Uteri dengan 
kejadian Kala II Lama Pada ibu bersalin terbukti secara statistik.

Dari hasil analisis diperoleh nilai Odds Ratio $(\mathrm{OR})=12,609$ artinya ibu bersalin yang mengalami Inersia Uteri mempunyai peluang terjadi Kala II Lama sebanyak 13 kali, dibandingkan ibu bersalin yang tidak mengalami Inersia Uteri

\section{PEMBAHASAN}

\section{Hubungan KPD Dengan Kejadian Kala II Lama Pada Ibu Bersalin Di Rumah Sakit Islam Siti Khadijah Palembang Tahun 2018}

Berdasarkan penelitian yang telah dilakukan Pada Ibu Bersalin Di Rumah Sakit Islam Siti Khadijah Palembang, dimana Ketuban Pecah Dini pada ibu bersalin dibagi menjadi 2 kategori yaitu "Ya KPD" (Jika Ibu Mengalami KPD) dan "Tidak KPD" (Jika Ibu Tidak Mengalami KPD).

Berdasarkan hasil analisis univariat, dapat dilihat dari 87 responden, proporsi ibu bersalin yang mengalami KPD adalah sebanyak 20 responden (23,0\%), lebih kecil dibandingkan dengan ibu bersalin yang tidak mengalami KPD yaitu sebanyak 67 responden $(77,0 \%)$

Dari hasil analisis bivariat, dari 20 responden dengan KPD, yang mengalami kala II lama sebanyak 12 responden $(60,0 \%)$ lebih besar dibandingkan dengan yang tidak mengalami kala II lama sebanyak 8 responden (40,0\%). Sedangkan dari 67 responden yang tidak dengan KPD yang mengalami kala II lama sebanyak 16 responden $(23,9 \%)$ lebih kecil dibandingkan dengan yang tidak mengalami kala II lama sebanyak 51 responden $(76,1 \%)$.

Proporsi ibu bersalin yang mengalami KPD dengan kala II Lama sebanyak $(60,0 \%)$ lebih besar dari pada ibu bersalin yang tidak mengalami KPD dengan kejadian kala II Lama sebanyak $(23,9 \%)$ yang mempunyai kecenderungan untuk mengalami persalinan kala II Lama di RSI Siti Khadijah Palembang.

Dari hasil uji chi-square diperoleh $P_{\text {_value }}(0,005)<\alpha(0,05)$, yang artinya ada hubungan yang bermakna antara Ketuban Pecah Dini (KPD) dengan kejadian Kala II Lama Pada ibu bersalin. Dengan demikian hipotesis yang menyatakan bahwa ada hubungan antara Ketuban Pecah Dini (KPD) dengan kejadian Kala II Lama Pada ibu bersalin terbukti secara statistik.

Dari hasil analisis diperoleh nilai Odds Ratio $(\mathrm{OR})=4.781$ artinya ibu bersalin yang mengalami KPD mempunyai peluang terjadi Kala II Lama sebanyak 4-5 kali, dibandingkan ibu bersalin yang tidak mengalami KPD.

Ketuban pecah dini adalah pecahnya selaput sebelum terdapat tandatanda persalinan mulai dan ditunggu satu jam sebelum terjadi inpartu terjadi pada pembukaan $<4 \mathrm{~cm}$ yang dapat terjadi pada usia kehamilan cukup waktu atau kurang waktu (Wiknjosastro, 2011).

Hal ini juga sejalan dengan penelitian sebelumnya bahwa dari 43 responden yang mengalami ketuban pecah dini dengan kala II lama sebanyak 33 orang $(76,7 \%)$ dan yang tidak mengalami ketuban pecah dini dengan kala II lama sebanyak 10 orang $(23,2 \%)$ dan berarti ada hubungan signifikan ketuban pecah dini dengan kala II lama (Eka, 2011).

Berdasarkan hasil di atas, peneliti menyimpulkan bahwa ada hubungan antara KPD dengan kejadian Kala II Lama Pada ibu bersalin, karena pada saat ibu mengalami KPD maka Pada kala 1 persalinan selaput ketuban dan bagian terbawah janin memainkan peran untuk membuka bagian atas vagina, bila selaput ketuban sudah pecah bagian terbawah janin yang menempel ke serviks dan membentuk segmen bawah uterus berfungsi sama hal ini akan mengakibatkan terjadinya proses persalinan yang lama. 
Hasil penelitian ini sejalan dengan teori bahwa Ibu yang mengalami ketuban pecah dini saat belum inpartu cenderung mengalami persalinan yang lama, sedangkan ibu yang mengalami ketuban saat inpartu mengalami waktu persalinan yang cenderung sesuai (Nita, 2016).

\section{Hubungan Janin Besar dengan Kejadian Kala II Lama Pada Ibu Bersalin Di Rumah Sakit Islam Siti Khadijah Palembang Tahun 2018}

Berdasarkan penelitian yang telah dilakukan Pada Ibu Bersalin Di Rumah Sakit Islam Siti Khadijah Palembang, dimana ibu bersalin yang mengalami Janin Besar dibagi menjadi 2 kategori yaitu: “ Ya Janin Besar" ( Jika BB > 4000 gram) dan "Tidak Janin Besar" (Jika BB $\leq 4000$ gram).

Berdasarkan hasil analisis univariat, dapat dilihat dari 87 responden, proporsi ibu yang mengalami Janin Besar adalah sebanyak 15 responden $(17,2 \%)$, lebih kecil dibandingkan dengan ibu yang tidak mengalami Janin Besar yaitu sebanyak 72 responden $(82,8 \%)$.

Dari hasil analisis bivariat, dari 15 responden dengan Janin Besar, yang mengalami kala II lama sebanyak 9 responden $(60,0 \%)$ lebih besar dibandingkan dengan yang tidak mengalami kala II lama sebanyak 6 responden (40,0\%). Sedangkan dari 72 responden tidak dengan Janin Besar yang mengalami kala II lama sebanyak 19 responden (26,4\%) lebih kecil dibandingkan dengan yang tidak mengalami kala II lama sebanyak 53 responden $(73,6 \%)$.

Proporsi ibu bersalin yang mengalami Janin Besar dengan kala II Lama sebanyak $(60,0 \%)$ lebih besar dari pada ibu bersalin yang tidak mengalami Janin Besar dengan kejadian kala II Lama sebanyak $(26,4 \%)$ yang mempunyai kecenderungan untuk mengalami persalinan kala II Lama di RSI Siti Khadijah Palembang.

Dari hasil uji chi-square diperoleh $P$ _value $(0,016)<\alpha(0,05)$, yang artinya ada hubungan yang bermakna antara Janin Besar dengan kejadian Kala II Lama Pada ibu bersalin. Dengan demikian hipotesis yang menyatakan bahwa ada hubungan antara Janin Besar dengan kejadian Kala II Lama Pada ibu bersalin terbukti secara statistik.

Dari hasil analisis diperoleh nilai Odds Ratio $(\mathrm{OR})=4.184$ artinya ibu bersalin yang mengalami Janin Besar mempunyai peluang terjadi Kala II Lama sebanyak 4 kali, dibandingkan ibu bersalin yang tidak mengalami Janin Besar.

Makrosomia atau bayi besar adalah bila berat badan bayi melebihi dari 4000 gram. Dalam dunia kedokteran makrosomia disebut giant baby (Prawirohardjo, 2011).

Hal ini sejalan dengan penelitian sebelumnya bahwa hasil analisa bivariat pada pasien kala II lama berjumlah 76 responden dengan janin besar sebanyak 11 ibu $(44 \%)$ dan pasien kala II lama tidak dengan janin besar sebanyak 65 ibu (17\%) Jadi, lebih banyak pasien kala II lama dengan janin besar dibandingkan pasien kala II lama yang tidak dengan janin besar (Pamingki Ritno A.R, 2015).

Berdasarkan hasil di atas, peneliti menyimpulkan bahwa ada hubungan antara Janin Besar dengan kejadian Kala II Lama Pada ibu bersalin, Ibu bersalin yang mengalami Janin Besar terjadi sebagian karena Obesitas atau kelebihan berat badan saat hamil, menderita diabetes, dan mempunyai riwayat Janin Besar sebelumnya, sehingga kelahiran karena janin Besar atau makrosomia dapat menyebabkan persalinan kala II Lama.

Hasil penelitian ini sejalan dengan teori bahwa Ukuran janin yang besar sangat menyulitkan kelahiran karena makrosomia, bagi ibu melibatkan distensi uterus, peregangan berlebih pada serat- 
serat uterus yang menyebabkan disfungsional persalinan, kemungkinan rupture uterus dan peningkatan insiden perdarahan post partum dan persalinan dapat menjadi lebih lama (Hamilton, 2009).

\section{Hubungan Inersia Uteri dengan Kejadian Kala II Lama Pada Ibu Bersalin Di Rumah Sakit Islam Siti Khadijah Palembang Tahun 2018}

Berdasarkan penelitian yang telah dilakukan Pada Ibu Bersalin Di Rumah Sakit Islam Siti Khadijah Palembang, dimana ibu bersalin yang mengalami Inersia Uteri dibagi menjadi 2 kategori yaitu :"Ya Inersia Uteri" (Jika His Tidak Adekuat) dan "Tidak Inersia Uteri" (Jika His adekuat).

Berdasarkan hasil analisis univariat, dapat dilihat dari 87 responden yang diteliti, proporsi Ibu Yang Mengalami Inersia Uteri adalah sebanyak 6 responden (6,9\%), lebih kecil dibandingkan dengan ibu yang tidak mengalami inersia uteri yaitu sebanyak 81 responden $(93,1 \%)$.

Dari hasil analisis bivariat, dari 6 responden dengan Inersia Uteri, yang mengalami kala II lama sebanyak 5 responden $(83,3 \%)$ lebih besar dibandingkan dengan yang tidak mengalami kala II lama sebanyak 1 responden $(16,7 \%)$. Sedangkan dari 81 responden yang tidak dengan Inersia Uteri yang mengalami kala II lama sebanyak 23 responden $(28,4 \%)$ lebih kecil dibandingkan dengan yang tidak mengalami kala II lama sebanyak 58 responden $(71,6 \%)$.

Proporsi ibu bersalin yang mengalami Inersia Uteri dengan kala II Lama sebanyak $(83,3 \%)$ lebih besar dari pada ibu bersalin yang tidak mengalami Inersia Uteri dengan kejadian kala II Lama sebanyak $(28,4 \%)$ yang mempunyai kecenderungan untuk mengalami persalinan kala II Lama di RSI Siti Khadijah Palembang.

Dari hasil uji chi-square diperoleh $P_{\text {_value }}(0,012)<\alpha(0,05)$, yang artinya ada hubungan yang bermakna antara Inersia Uteri dengan kejadian Kala II Lama Pada ibu bersalin. Dengan demikian hipotesis yang menyatakan bahwa ada hubungan antara Inersia Uteri dengan kejadian Kala II Lama Pada ibu bersalin terbukti secara statistik.

Dari hasil analisis diperoleh nilai Odds Ratio $(\mathrm{OR})=12,609$ artinya ibu bersalin yang mengalami Inersia Uteri mempunyai peluang terjadi Kala II Lama sebanyak 13 kali, dibandingkan ibu bersalin yang tidak mengalami Inersia Uteri.

Inersia uteri adalah kelainan his yang kekuatannya tidak adekuat untuk melakukan pembukaan serviks atau mendorong janin keluar. Disini kekuatan his lemah dan frekuensinya jarang (Dhaniah, 2016).

Hal ini sejalan dengan penelitian sebelumnya bahwa hasil dari 69 orang porporsi kejadian kala II lama lebih tinggi pada inersia uteri 53 orang $(35,8 \%)$ dibandingkan dengan yang tidak inersia uteri yaitu $16 \quad(10,8 \%)$. Hal ini membuktikan bahwa Inersia uteri menyebabkan persalinan akan berlangsung lama sehingga dapat menyebabkan morbiditas ibu dan mortalitas janin (Riyanto, 2012).

Berdasarkan hasil di atas, peneliti menyimpulkan bahwa ada hubungan antara Janin Besar dengan kejadian Kala II Lama Pada ibu bersalin, Ibu bersalin yang mengalami Inersia Uteri sebagian terjadi karena kehamilan postmatur, kehamilan kembar dan ibu yang mengalami anemia, itulah yang menjadikan kontraksi uterus tidak adekuat sehingga menyebabkan persalinan kala II Lama.

Hasil penelitian ini sejalan dengan teori bahwa Kala II lama dapat terjadi akibat kelainan his antara lain inersia uteri yang sifat hisnya lemah, pendek dan jarang 
dari normal. Timbulnya his adalah indikasi mulainya persalinan, apabila his yang timbul sifatnya lemah, pendek, dan jarang maka akan mempengaruhi turunnya kepala dan pembukaan serviks atau yang sering disebut dengan inkoordinasi kontraksi otot rahim, dimana keadaan inkoordinasi kontraksi otot rahim ini dapat menyebabkan sulitnya kekuatan otot rahim untuk dapat meningkatkan pembukaan atau pengusiran janin dari dalam rahim, pada akhirnya ibu akan mengalami kala II lama karena tidak adanya kemajuan dalam persalinan (Manuaba, 2010).

\section{KESIMPULAN}

Berdasarkan hasil penelitian dengan judul "Hubungan KPD, Janin Besar dan Inersia Uteri dengan Kejadian Kala II Lama Di Rumah Sakit Islam Siti Khadijah Kota Palembang Tahun 2018”. yang telah diteliti, maka dapat ditarik kesimpulan sebagai berikut :

1. Ada hubungan KPD, janin besar dan inersia uteri secara simultan dengan kejadian kala II lama di Rumah Sakit Islam Siti Khadijah Kota Palembang Tahun 2018

2. Ada hubungan yang bermakna antara KPD secara parsial dengan kejadian kala II lama di Rumah Sakit Islam Siti Khadijah Kota Palembang tahun 2018

3. Ada hubungan yang bermakna antara janin besar secara parsial dengan kejadian kala II lama di Rumah Sakit Islam Siti Khadijah Kota Palembang 2018

4. Ada hubungan yang bermakna antara inersia uteri secara parsial dengan kejadian kala II lama di Rumah Sakit Islam Siti Khadijah Kota Palembang 2018.

\section{SARAN}

1. Bagi Rumah Sakit Islam Siti Khadijah Palembang

Dengan adanya penelitian ini secara langsung pihak rumah sakit bisa mengetahui dan mengantisipasi akan terjadinya persalinan kala II lama dan faktor penyebab serta sebagai informasi dalam meningkatkan mutu pelayanan di Rumah Sakit Islam Siti Khadijah Palembang.

2. Bagi Universitas Kader Bangsa Palembang

Sebagai bahan referensi untuk menambah kepustakaan dan menambah pengetahuan bagi mahasiswa, khususnya Diploma IV Kebidanan Universitas Kader Bangsa Palembang.

3. Bagi Peneliti

Menambah wawasan dan pengalaman dalam bidang metedologi penelitian, sekaligus sebagai media untuk mengemukakan pendapat secara objektif mengenai hubungan antara KPD, janin besar dan inersia uteri dengan kejadian kala II lama.

4. Bagi Peneliti yang Akan Datang

Menambah pengetahuan dan memperluas pengetahuan dalam melakukan kegiatan penelitian selanjutnya dalam bidang kesehatan dan dapat menjadi sumber informasi, serta pengetahuan sehingga bermanfaat untuk peneliti selanjutnya guna kesempurnaan yang akan dating sehingga bermanfaat bagi kita semua.

\section{UCAPAN TERIMA KASIH}

1. Allah yang maha pengasih lagi maha penyayang, Rabb semesta alam berkat rahmat dan kasih sayang sehingga penulis dapat menyelesaikan skripsi ini. Sholawat serta salam selalu tercurahkan kepada tauladan sepanjang masa, nabi Muhammad SAW, beserta para pengikutnya yang senantiasa istiqomah dalam sunahnya hingga akhir zaman.

2. Kedua orang tuaku tercinta, Ayahku (Supeno) yang selalu berusaha membahagiakan $\mathrm{q}$ dengan cara dan usahanya dan Ibuku tersayang (Kasmiati) yang selalu mendoakan 
disepertiga malamnya, kakak (Eka Triwahyuni) dan adiku (Fikri Satrio Permadi) yang selalu memberi semangat, teruntuk juga calon imam $\mathrm{ku}$ sasmito yang slalu memberi semangat dan motifasi, Kalian segalanya bagiku, I just simply let you know that $i$ love you so much, everything you have given to me and every lesson you have taugh me have help me become who i'm today. You're really the best parents in the world

3. Untuk pembimbingku ibu $\mathrm{Hj}$. Herawati, M.Kes dan ibu Rizki Amalia, SST., M.Kes yang telah membantu dan membimbing dengan penuh kesabaran dalam menyelesaikan Skripsi ini.

4. Untuk sahabatku (Ema, Ari, Jeza, Diana, ade, mami amrina) yang selalu membantu dan memotifasiku

5. Untuk teman Sepembimbingku (D5: Dewi Sumdika, Dewi Aprilia s, Dewi Anggraini, Dian F) yang sama-sama berjuang untuk menyelesaikan Skripsi ini

6. Untuk semua teman sealmamater ku

\section{DAFTAR PUSTAKA}

Andriani dan Eka, P.2014.Jurnal Janin Besar Dan Inersia Uteri Terhadap Kala II Lama. Surabaya: Fakultas Ilmu Kebidanan, Universitas Airlangga

Dinas Kesehatan provinsi Sumatra Selatan. 2017.

http://dinkes.sumselprov.go.id/

Guyton.A.C.dan John E.H. 2008. fisiologi kedokteran. Jakarta. EGC.

Jurnal Penelitian Nita,dkk.2016.Hubungan KPD Terhadap Kala II Lama

Manuaba.2008. Gawat darurat Obstetri Ginekologi dan Obstetri Ginekologi sosial untuk profesi Bidan.Jakarta: EGC.

Manuaba, Ida Bagus Gde. 2010. Ilmu Kebidanan Penyakit Kandungan dan Keluarga Berencana Untuk Pendidikan Bidan. Jakarta : EGC

Notoatmodjo, S. 2012. Metodologi Penelitian Kesehatan.Jakarta: Renika Cipta.

Prawirohardo. 2011. Ilmu Kebidanan. Jakarta: Bina Pustaka Sarwono Prawirohardjo

R.A. Pamingki Ritno, 2015. Partus lama.tersedia di: http//Rumah bidan blogspot.com/2015/06/partus lama html. Diakses tanggal 23 desember 2016.

Profil RS Islam Siti Khadijah Palembang Tahun 2019

Riyanto. 2012. http:// jurnal. FK Unand.ac.id, jurnal kesehatan.2015/ diakses pada tanggal 06 mei 2019

SDKI. 2018. http://sdki.bkkbn.go.id/lang=dataseti $d=195$.

WHO. 2017. http://r.search.yahoo.com

Wiknjosastro, Hanifa. 2011. Ilmu

Kebidanan Edisi 3. Jakarta: YBPSP. 